\title{
Idrætshistorisk værksted
}

\author{
af Ove Korsgaard
}

På Gerlev Irætshøjskole har vi besluttet at oprette en selvejende institution, der skal søge at realisere planerne om et idrætshistorisk værksted.

\section{Formål:}

1. at forske i og gøre forsøg med før-sportslige idrætsformer og deres samspil med de natur- og kulturgivne forudsætninger.

2. at formidle viden om fortidens idrætter og derigennem stimulere debatten om udviklingen af nutidens og fremtidens idrætter.

\section{Arbejdsområder:}

1. Forskning og forsøg.

Idrætshistorisk værksted skal indsamle viden og materiale fra fortidige idrætsformer og forsøge sig med, hvordan disse har været udøvet $\mathrm{i}$ praksis, hvordan reglerne har været, redskaberne, miljøet, påklædningen, symbolerne m.v. Værkstedet skal drive forskning af idrætshistorisk og tværvidenskabelig art og aktivt indgå i det internationale samarbejde på de relevante felter.

2. Formidling.

Idrætshistorisk værksted skal formidle historisk viden gennem aktivitet ud fra den pædagogiske tanke, at indlæring og bevægelse er knyttet tæt sammen. For at kunne ,forstå" en leg som ,,so i hul" er det nødvendigt at lege den. Skoler, klubber, foreninger og offentligheden skal have mulighed for selv at deltage i og afprøve de forskellige former for idræt. De deltagende skal have lejlighed til at opleve og erfare idrætsformer på det historiske miljøs betingelser. - Men ud over at deltage i praksis er det vigtigt, at deltagerne også ser gamle genstande, film og lysbilleder, bruger arbejdshæfter og arbejdsblade, hører foredrag og lydbånd, der kan uddybe forståelsen. 
3. Kursusvirksomhed.

Idrætshistorisk værksted skal afholde kurser, hvor resultaterne af forsknings- og forsøgsarbejdet skal videregives. Målgruppen er lærere i folkeskolen, ungdomsskolen, universitetsstuderende, lærerstuderende samt ledere inden for ungdoms- og idrætsarbejde. Ligesom der andre steder afholdes kurser i gammel folkedans og folkemusik, så man kan danse og spille de gamle former og bruge dem i nye sammenhænge, skal Idrætshistorisk Værksted afholde kurser i gamle lege, spil og danse - så de kan bruges og måske blomstre.

\section{Baggrund}

Når vi går en tur gennem en gammel by, kan vi se, hvordan byggestilen har ændret sig gennem tiderne. Vi har inden for arkitektur forskellige stilperioder. I højmiddelalderen var det den gotiske stil, der var mode. Det særlige ved denne stil er det himmelstræbende; alt stræbte opad, op mod himlen, ind i himlen - med spir, med takker, blomster og først og fremmest spidsbuer. Sådan skulle det være, når det skulle være rigtigt og fornemt.

Men en dag blev man træt af at se på de bygninger. Der skete et brud $\mathrm{i}$ arkitekturen, og man begyndte at bygge på en ny måde. Det skete selvfølgelig ikke fra den ene dag til den anden, og det skete heller ikke samtidig i de forskellige lande i Europa. Den tid kom, der kaldtes renæssancen, der betyder genfødsel. Men i virkeligheden var det en tid med vældige nybrud $i$ Europa. Det sås i politik, handel, kunst, religion, videnskab, arkitektur m.v. Inden for arkitekturen betød det, at man i stedet for at understrege de lodrette linier gik over til at fremhæve de vandrette; alt blev stillet op i lange rækker, vinduer sattes i geledder, udskæringer i kister og skabe i lige linie efter hinanden.

Alt, hvad der her er sagt om bygninger, kan også siges óm idræt. For på samme måde som vi med en stil giver vore bygninger forskellige udformninger, former vi også idrætten eller legemskulturen gennem forskellige stilarter.

Inden for arkitekturen er nogle af de mest kendte stilarter: gotik, renæssance, barok, rokokko, nyklassicisme. Og inden for legemskulturen har følgende stilarter været fremtrædende gennem de sidste 200 år: adelige eksercitier, tysk gymnastik, svensk gymnastik og engelsk sport.

Sport er i dag den mest udbredte stilart inden for legemskulturen. Mange sætter derfor lighedstegn mellem sport og legemskultur, men det vil svare til at sætte lighedstegn mellem gotik og arkitektur. Sport og gotik er historiske former inden for legemskultur og arkitektur. 
Ved at vandre gennem en gammel by kan vi som sagt se, hvordan arkitekturen udformes til forskellige tider. Vi kan se hvordan - og til hvad folk byggede; og vi kan ud fra bygningernes udseende fortolke, hvad de tænkte, følte og lagde vægt på.

Vi kan ikke på samme måde vandre tilbage i legemskulturens historie, bl.a. af den simple grund at leg, spil og dans kun er synlig, når der leges, spilles og danses. Når en bygning er færdig kan den ses i årtier, ja, i mange tilfælde i århundreder. Idræt, derimod, kan man kun se, når der er bevægelse. Går et spil af mode, kan man ikke længere se det.

Dog kan det på visse områder lade sig gøre at se gamle stilarter inden for legemskuturen. Går vi i cirkus og ser på hestenumrene, så er det faktisk en af de vigtigste idrætter fra 16-1700-tallet, vi ser. Kunstridning havde dengang stor betydning $i$ adlens opdragelse. I dag har den skiftet funktion: fra opdragelse til underholdning og symbolindholdet er også et andet. Danser vi menuet til en skolefest, så gentager vi en anden af de adelige eksercitier, nemlig den høviske dans, som også var en af de vigtige idrætter i den periode. Og når soldaterne er på den militære feltbane, så gentager de det, der var hovedindholdet i den tyske gymnastik i en stor del af 1900-tallet.

\section{Fra museum til værksted}

Der eksisterer ikke noget idrætsmuseum, som der eksisterer kulturhistoriske museer. Det skyldes nok de store omkostninger, der er forbundet med at lave museum, men sikkert $i$ endnu højere grad, at det er svært at give et idrætsmuseum et fornuftigt idémæssigt indhold. At se på rekvisitter, fotografier og resultatlister er ikke en udfordring, der for alvor involverer de besøgende. Det er i denne sammenhæng sigende, at Nationalmuseets udstilling i Brede i 1972, „For sportens skyld“, ikke blev den ventede publikumsucces.

At den ikke blev det, er forståeligt, hvis man ser nærmere på forholdet mellem idræt og museum. Hvis man ved legemskultur forstår en form for menneskelig bevægelseskultur, så er den som sådan allerede næsten uforenelig med begrebet museum - dvs. en rumlig-statisk indretning af materielle genstande. Det gælder specielt for forhistoriske (og etnologiske) bevægelseskulturer, der kun i ringe grad er blevet tingsliggjort, f.eks. i form af særligt fremstillede sportsredskaber. Begrebet museum er derfor ikke velegnet til opgaven: at vise bevægelsesformer. At gøre det peger ud over museets grænser - $i$ retning af et forsøgsværksted.

Igennem 25 år har Historisk-Arkæologisk Forsøgscenter ved Lejre vist, hvordan et sådant projekt kan realiseres, når det gælder etnologiske og 
arkæologiske eksperimenter. Her er der blevet anlagt bebyggelser fra sten-, bronze- og jernalderen. Her kan man selv lave værktøj af sten, skyde med bue og pil, pløje med en simpel art, lave mad, slæbe sten til en kæmpehøj, danse i labyrint m.v.

På Gerlev Idrætshøjskole har vi også gennem en årrække arbejdet med historiske lege, spil og danse. Vi har arbejdet med sværddans fra middelalderen, adelige eksercitier, tysk gymnastik og svensk gymnastik og også idrætter fra østlige og afrikanske kulturer. Her skal antydes et eksempel på, hvilke muligheder for historisk erkendelse, der ligger i gamle idrætter som f.eks. „,høvisk gang“ og ,so i hul“. Under enevælden var det kendte aktiviteter $\mathrm{i}$ henholdsvis adelsstanden og bondestanden.

\section{Høvisk gang og so i hul}

Som bekendt betød Enevælden, at Kongen og hans familie alene stod $\mathrm{i}$ spidsen for landet. Over ham var kun Gud, og den enevældige konge var derfor ,Konge af Guds nåde“. Under kongen fordelte de forskellige stænder sig som lagene i en pyramide. Lige under kongen var aristokratiet, der bestod af adlen og de allerfineste af embedsmændene. Under dem kom de største af borgerne i byen, der som oftest var købmænd. I bunden af pyramiden var så resten af befolkningen, og det var langt den største gruppe. Her var fæstebønder, der arbejdede for godsejeren, og arbejderne i byerne, som der dog ikke var mange af. Til gengæld var der mange tjenere og tjenestefolk. Under pyramiden - helt uden for systemet - var de allerfattigste, tiggerne og omstrejferne, som man så på med foragt og ofte spærrede inde for at få dem til at arbejde. Der eksisterede i alt 9 rangklasser med i alt 97 rangtrin, og så var det endda langt fra alle, der havde rang.

I dette samfund var det vigtigt for dem i toppen af pyramiden at vise og demonstrere over for andre, hvilken stand de selv tilhørte, og hvor de andre hørte hjemme. Det blev gjort på utrolig mange og raffinerede måder.

En af dem var gennem arkitekturen. Kongen og adlen byggede kæmpeslotte, der var alt for store at bo i, men med denne pragtudfoldelse demonstrerede man sin betydning. Man gjorde det også ved at gøre selv de mest almindelige ting som at sove, spise, elske og køre tur til endeløse ceremonier, der besværliggjorde livet. Blot det at køre til byen blev til en indviklet affære, der krævede et stort optog med flere vogne, ryttere, løbere og mange tjenere.

At opdrage aristokratiets børn var derfor en kunstfærdig sag. Noget af det, der blev brugt megen tid på i opdragelsen, var at lære ærbødig tale og skrivning. Til hjælp havde man særlige lærebøger, der indeholdt regler om, 
hvordan et brev skulle skrives. I 1742 blev der udgivet en bog på 800 sider med anvisninger på, hvoran man f.eks. skulle tilskrive en stiftprovst: ,Deres Vel-ÆErværdighed, Vel-ÆEdle og Vel-Lærde Hr. (navnet) Stift-Provst over Sockelunds Herred og Sogne-Præst til Vor Frue Kirke i Kiøbenhavn." Til en „ustuderet" degn derimod skulle brevet indledes således: ,„Erlige og Velagtede Mand (navnet) Degn til Beldringe Kirke i Beldringe."

Opdragelsen drejede sig imidlertid ikke kun om at lære et bestemt skriftsprog, men i ligeså høj grad om at lære et bestemt kropssprog: Og det blev indlært gennem den tids idrætter, hvoraf høvisk dans hørte til de vigtigste. Gennem dem lærte man høvisk optræden. I 1742 blev en meget brugt instruktionsbog oversat til dansk med titlen "Dantse-Exercitii Nytte“, hvor der var en minutiøs beskrivelse af, hvordan man skulle gå på en høvisk måde.

Enevælden er således ikke kun en bestemt måde at tænke på, ej heller kun en bestemt måde at organisere samfundet på, nej, det er også en bestemt måde at gå på! At lære honnet, elegant, agtværdig, velanstændig, sirlig, ærbødig og høvisk optræden, havde også en kropslig side. Og det blev som sagt lært gennem den tids idrætter.

ÆErbødighedssprogets forskellige former var kun noget de rigeste og fornemste lærte. Men det betød på den anden side ikke, at resten af befolkningen ikke skulle vise ærbødighed. Det skulle de frem for nogen. Men i stedet for at lære ærbødighedssproget, måtte de nøjes med at lære lydighed.

Og det lærte de på så mange forskellige måder. Nok også gennem deres lege og spil. Det er i hvert fald et gennemgående træk i mange af bondestandens lege og spil, at man ikke blev præmieret for at stikke snuden for langt frem. At undgå at tabe var derimod vigtigt. „So i hul" er et eksempel. I spillet er der et hul mindre end antal deltagere. Det gælder derfor om at sikre sig et hul. Hvis der er syv deltagere, er der kun huller til de seks - den syvende er taber, hvorimod der ikke er en vinder.

Det at undgå at blive sidst var et gennemgående træk også i høstskikke og drillerier, i fortællinger og remser. „Den der kommer allersidst, skal i den sorte gryde. "Og den der blev sidst færdig med at høste fik al skrammel fra de andre gårde ind på gårdspladsen. I legene indgik det ofte, at taberen fik en straf. Han skulle i fængsel, have nogle drag af krabasken eller løbe spidsrod ned gennem to rækker, hvor deltagerne måtte slå taberen mere eller mindre symbolsk.

Gennem disse skikke synes bondestanden at minde sig selv om, at det vigtigste her $\mathrm{i}$ livet ikke var at vinde, men at undgå at tabe. Stak man snuden for langt frem, så gjaldt jantelovens bud ,,Du skal ikke tro, du er noget", faldt man for langt tilbage, så risikerede man at falde helt ud af pyramiden, ud til 
landsbytossen, tiggeren og omstrejferen. Det var en stor præstation i bondesamfundet at undgå at blive sidst. Og gennem lege og spil fik de dette budskab ind $\mathrm{i}$ kroppen.

\section{Hvorfor idrætshistorie?}

Ligesom det er vigtigt at lære noget om kulturhistorie, er det vigtigt at lære noget om den måde kulturen bliver legemliggjort på gennem idrætten. Det kan være med til at give en forståelse af, at kulturelle normer og værdier også i dag legemliggør sig gennem idrætten.

Det er der behov for, idet sporten som den dominerende stilart inden for legemskulturen, synes at have nogle udviklingstræk $i$ sig, der er yderst problematiske. Sportens idealer bliver udtrykt i det olympiske motto: hurtigere - højere - stærkere. Men en fortsat udvikling af sporten efter dette ideal viser et skræmmende perspektiv, som selv nogle af sportens egne topledere gør opmærksom på. Generalsekretæren i det vesttyske sportsforbund $H$. Giseler skriver således, at det største problem i international sport er, at man i laboratorier udvikler nationale frankensteinere, der kan gøre sig gældende og sætte nye rekorder. Giseler siger, at topsportens betydning nok vil være opbrugt år 2000: „Allerede nu fornemmer vi, at rekord ikke længere bringer nogen fremskridt, der gør os lykkeligere, og at den ikke længere er betydningsfuld, men kun et instrument. Mere ved vi ikke, og dog ved vi, at der altid vil være idræt. Men den vil være anderledes, end vi kender den i dag, og denne viden er allerede en ny begyndelse."

Set i det perspektiv får (idræts)historie stor aktualitet. Gennem studier af og forsøg med vor egen idrætshistorie kan man se en idræt, der er anderledes, og dermed skabe baggrund for en stillingtagen til udviklingen af nutidens idræt. 